Revista Brasileira de Farmacognosia Brazilian Journal of Pharmacognosy 21(6): 1096-1103, Nov./Dec. 2011

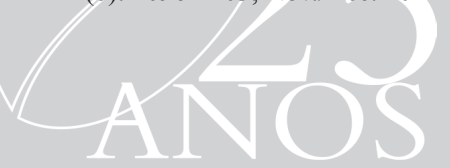

Article

Received 11 Jan 2011

Accepted 21 Mar 2011

Available online 19 Jun 2011

Keywords:

acute oral toxicity

Cyclea peltata

Menispermaceae

microscopy

peptic ulcer

ISSN 0102-695X

http://dx.doi.org/10.1590/S0102-

$695 \times 2011005000168$

\section{Pharmacognostical, antioxidant and antiulcer screening of Cyclea peltata roots}

\author{
David Raj Chellappan," Jipnomon Joseph, Parimaladevi \\ Balasubramanian
}

Division of Pharmacology and Toxicology, Centre for Advanced Research in Indian System of Medicine, SASTRA University, Thanjavur District, Tamil Nadu State, India.

\begin{abstract}
Cyclea peltata Hook. f. \& Thomson, belongs to the family Menispermaceae commonly known as "paatha", is a climbing shrub found throughout South and East India. In Indian traditional medicine the tuberous roots are also used to treat jaundice, stomachache, fever and asthma. This study deals with the microscopic study of leafs and roots of $C$. peltata, along with the physico-chemical, preliminary phytochemical analyses and antioxidant properties. Acute oral toxicity study was conducted as per OECD-423 guidelines and the extract was found to be devoid of any conspicuous acute toxicity in extract treated animals and no mortality upto $2 \mathrm{~g} / \mathrm{kg}$ by oral route. Hydroalcoholic extract of C. peltata in a dose dependant manner (125 and 250 $\mathrm{mg} / \mathrm{kg}$. p.o.) showed significant gastric protection against the ethanol-induced gastric ulcer model in rats.
\end{abstract}

\section{Introduction}

Cyclea peltata Hook. f. \& Thomson, Menispermaceae, is locally called "Padathaali/ Padakkilangu". It is a much branched climbing shrub found throughout south and east India with tuberous roots, peltate leaves, greenish yellow flowers and drupaceous fruits. Tuberous roots of the plant are used in the treatment of jaundice, stomachache, fever, nephrolithiasis (Christina et al, 2002), asthma (Valiathan, 2003) and Type 2 diabetics (Kirana \& Srinivasan, 2010). C. peltata roots are reported to contain tetrandrine, a bisbenzylisoquinoline dioxine alkaloid is well known for its antioxidant activity (Rastogi \& Mehrotra, 1999; $\mathrm{Ng}$ et al., 2006). In spite of the numerous medicinal uses recognized to this plant, there is no pharmacognostical report on the anatomical and other physico-chemical standards required for the quality control of the crude drug. Hence the present investigation includes macroscopy, microscopy, physico-chemical evaluation, fluorescence characters of powder and preliminary phytochemical evaluation and antioxidant property of different extracts of $C$. peltata roots. The hydro-alcoholic (30:70) extract was used for evaluating in vitro acid neutralizing capacity and in-vivo acute oral toxicity and ethanol induced gastric ulcer in Wistar rats.

\section{Materials and Methods}

\section{Collection of plant materials}

The plant specimens for the proposed study were collected from Kuzhanthupuzha, Kerala, India. The specimens were identified and authenticated by Botanical Survey of India, Tamilnadu Agricultural University, Coimbatore, Tamil Nadu, India (Ref. BSI./ SC/5/23/07-08/Tech.1226, Dt.: 28-11-2007.). A voucher specimen has been deposited in the Herbarium of Centre for Advanced Research in Indian System of Medicine, SASTRA University, Thanjavur District, Tamilnadu state, India. (Voucher No. C0146).

\section{Chemicals and instruments}

All the chemicals used were of highest available purity and were procured from E. Merck, Mumbai, India, HiMedia Laboratories, Mumbai, India and SD Fine Chemicals, Mumbai, India. ABTS was purchased from Sigma-Aldrich chemical Co. (St. Louis, MO). Photographic of different magnification were taken with Nikon Labophot 2 Microscopic unit. 


\section{Organoleptic evaluation}

In organoleptic evaluation, color and odour of the extracts were evaluated on visual and sensual basis.

\section{Macroscopical and microscopical evaluation}

Transverse section of leaf and root

Care was taken to select healthy plants and for normal organs. The leaf and root were cut and removed from the plant and fixed in formalin acetic acid solution (formalin:acetic acid:70\% ethyl alcohol in the ratio of 0.5:0.5:9). After $24 \mathrm{~h}$ of fixation, the specimens were dehydrated with graded series of tertiary-butyl alcohol as per the schedule given by Sass, 1940. Infiltration of the specimens was carried by gradual addition of paraffin wax $\left(58-60^{\circ} \mathrm{C}\right)$ until thiobarbituric acid solution attained super saturation. The specimens were then casted out into paraffin blocks. The paraffin embedded specimens were sectioned with the help of a rotary microtome and 10-12 $\mu \mathrm{m}$ thickness of the sections was made. However, dewaxing of the sections was done using customary procedure (Johansen, 1940). The sections were later stained with toluidine blue (O'Brien et al, 1964). Since, toluidine blue is a polychromatic stain; the staining was remarkably good and yielded varied cytochemical reactions. The dye rendered pink color to the cellulose walls, blue to lignified cells, dark green to suberin, violet to the mucilage, blue to the protein bodies etc. Cleared sections were then mounted with glycerine for microscopical observation. Microscopic descriptions of tissues are supplemented with micrographs wherever necessary. Photomicrographs of different magnifications were taken with Nikon Labophot 2 microscopic unit. For normal observation, a bright field microscopy was used and for the study of crystals, starch grains and lignified cells, a polarized light was employed. However, since these structures have birefringent property, under polarized light they tend to appear bright against the dark background. Magnifications of the figures are indicated by the scale-bars. Descriptive terms of the anatomical features are as per the standard anatomy books (Esau, 1964). Powder microscopic analysis was done by placing little quantity of powder onto a microscopic slide, 1-2 drops of $0.1 \%$ phloroglucinol solution and a drop of concentrated hydrochloric acid were added and covered with a cover slip. The slide preparation was mounted in glycerol and examined under microscope. Presence of starch grains was detected by the formation of blue color on addition of 2-3 drops of $0.01 \mathrm{M}$ iodine solution.

Physicochemical evaluation

The percentage of ash values and extractive values were performed according to official methods prescribed (Indian Pharmacopoeia, 1996; The Ayurvedic Pharmacopoeia of India, 1989) and the WHO guidelines on quality control methods for medicinal plant materials (WHO/QCMMPM guidelines, 1992). The determinations were performed in triplicate and the results are expressed as mean \pm SEM. The percentage $\mathrm{w} / \mathrm{w}$ values were calculated with reference to the air-dried drug. The fluorescence characters of the powder with various acids were observed under visible light and UV light as per the procedure (Kokoshi et al., 1958; Chase \& Pratt, 1949). The preliminary phytochemical screening of powdered root sample was screened for the presence of various groups of phytoconstituents using different chemical tests described by Harborne (1998) and Kokate et al. (2002).

\section{ABTS free radical scavenging assay}

The free radical scavenging ability was determined using ABTS radical cation decolorization assay (Re et al., 1999). Generation of radical cation $\left(\mathrm{ABTS}^{+}\right)$involves the reaction between ABTS and potassium persulfate and production of the blue/green ABTS chromophore with a maximum absorption at $734 \mathrm{~nm}$. In presence of antioxidants, the pre-formed radical cation is reduced to ABTS, proportionally to the antioxidant activity. Briefly, the stock solution which was allowed to stand in the dark for $16 \mathrm{~h}$ at room temperature contained equal volumes of $7 \mathrm{mM}$ ABTS salt and $2.4 \mathrm{mM}$ potassium persulfate. The resultant $\mathrm{ABTS}^{++}$solution was diluted with methanol until an absorbance of about $0.70 \pm 0.01$ at $734 \mathrm{~nm}$ was reached. Three different concentrations (50,100 and $150 \mu \mathrm{g} / \mathrm{mL}$ ) of petroleum ether, chloroform, ethyl acetate, ethanol and water extracts was reacted with $1 \mathrm{~mL}$ of ABTS solution and the absorbance taken at $734 \mathrm{~nm}$ between 3-7 min using the spectrophotometer. The percentage inhibition was calculated as:

ABTS radical scavenging activity $(\%)=[($ Abs controlAbs sample)(Abs control)] x 100

where, Abs control and Abs samples are the respective was the absorbance of ABTS radical+methanol; Abs sample was the absorbance of ABTS radical+extract sample

\section{Acid buffering activity}

Cyclea peltata Hook. f. \& Thomson, Menispermaceae, root powder $(500 \mathrm{mg}$ ) was added to 2 $\mathrm{mL}$ of distilled water, which was treated with $10 \mathrm{~mL}$ of $\mathrm{HCl}(\mathrm{pH} 1.0)$, while $2 \mathrm{~mL}$ of distilled water was added in the controlled test tubes in addition to above $10 \mathrm{~mL}$ of $\mathrm{HCl}$ solution. The $\mathrm{pH}$ values were measured after 1 and 
30 min (Rifat-uz-Zaman et al., 2002).

\section{Preparation of plant extracts}

The powdered root (200 g) of the plant was submitted to dynamic maceration with ethanol $70 \%$ for $4 \mathrm{~h}$. This procedure was repeated three times with the same powder. After filtration, the residue was discarded and the solvent evaporated under reduced pressure and the extract was dried, yielding a dark brown semisolid (41.36 g), designated as the HACP (Ali, 2003). The yield of hydro-alcoholic extract was $20.68 \% \mathrm{w} / \mathrm{w}$ and stored in refrigerator for further use. The extract at doses of 125 and $250 \mathrm{mg} / \mathrm{kg}$ was suspended in $1 \%$ of Tween 80 and administered to animal.

\section{Experimental animals}

Male Wistar Albino rats, weighed 200-250 g (aged 4 months) were utilized in this study. They were housed in cages under standard laboratory conditions (light period 7.00 a.m. to 7.00 p.m., $21 \pm 2{ }^{\circ} \mathrm{C}$, and relative humidity $55 \%$ ). The animals were given standard rat pellets and tap water ad libitum, but they were deprived of food $24 \mathrm{~h}$ before the experiments. The rats were acclimatized to laboratory condition for 7 days before commencement of experiment. All procedures involving laboratory animal use were in accordance to the Institute Animal Ethics Committee regulations approved by the Committee for the Purpose of Control and Supervision of Experiments on Animals (CPCSEA) and the approval number is 44/SASTRA/IAEC/RPP.

\section{Acute toxicity test}

Acute oral toxicity was performed in female rats as per OECD-423 guidelines (OECD, 2001). All the rats were administered with a single oral dose of hydroalcoholic extract of $C$. peltata root extract at the dose of $2000 \mathrm{mg} / \mathrm{kg}$, b.wt by oral route dissolved in $1 \mathrm{~mL}$ of $1 \%$ tween 80 used as the vehicle. Feeding was done using gastric feeding tube. Each animal was observed each time for the first 5 min after loading for signs of regurgitation and then kept in individual polypropylene rat cage. Each animal was observed for every $15 \mathrm{~min}$ in the first $4 \mathrm{~h}$ after dosing, then every $30 \mathrm{~min}$ for the successive $6 \mathrm{~h}$ and then daily for the successive $48 \mathrm{~h}$ for the short-term outcome and the remaining 14 days for the long-term possible lethal outcome which in this case was death. The animals were observed for signs of convulsions, tremors, circling, depression, excitement and mortality. The surviving animals were sacrificed under high dose of anesthesia, autopsied and examined macroscopically for any pathological changes.

\section{Ethanol induced gastric ulcer model}

The ethanol induced gastric ulcer was performed according to Suleyman et al. (2002) and Robert et al (1979). All rats were fasted for $48 \mathrm{~h}$ before the experiment but excess water were allowed and just two hours before starting the experiment water also were removed. To avoid coprophagy the rats were fasted in wire-bottomed cages. Group 1 animals served as vehicle control group and they received 1\% Tween 80 as vehicle equivalent to the volume of test drug. Group 2 animals were assigned as standard drugs treatment group and they received sucralfate $(400 \mathrm{mg} / \mathrm{kg})$ by oral route. Group 3 and 4 animals were received hydro-alcoholic extract of $C$. peltata at the dose of 125 and $250 \mathrm{mg} / \mathrm{kg}$ by oral route. One hour after the vehicle, standard and test drug treatment, all the animals were gavaged with absolute ethanol ( $5 \mathrm{~mL} / \mathrm{kg}$ b.wt.).

\section{Gross gastric lesions evaluation}

Assessment of gastric lesions was also carried out by gross pathological examination of the stomach mucosa. One hour after ethanol administration, the animals were euthanized by high dose of anesthesia. The stomachs were excised, cut along the greater curvature, and gently rinsed under ice cold phosphate buffer saline. Massive gastric hemorrhage was observed in the rats' stomachs $1 \mathrm{~h}$ after oral administration of absolute ethanol. The stomachs were stretched on a frog board with mucosal surface up then to be examined in a standard position for macroscopic examination and the scoring of ulcer was performed with the help of a magnifying hand lens. The mucosa was examined for the number of absolute ethanol-induced mucosal lesions (GutierrezCabano, 2000). The ulcer area (UA) was calculated by using ENVI 4.3 according to Haseeb (2004).

The total ulcer area $\left(\mathrm{mm}^{2}\right)$ of each stomach was recorded and the \% protection was calculated as follow:

$\%$ Protective $=$ UA control- $($ UA treatment $) /$ UA control $\times 100$

Ulcer index (UI) was calculated as follow:

Ulcer Index =10/X

where, $\mathrm{X}=$ Total mucosal area/Total ulcerated area

\section{Statistical analysis}

Statistical analysis of the results was done using the statistical functions of the Graphpad Prism 5.0 software. The results were expressed in terms of mean \pm SEM. The significance of difference between mean values for the various treatments were tested using one 
way analysis of variance test (ANOVA test) followed by Dunnett Multiple Comparisons Test and the $\mathrm{p}$ values less than 0.05 were considered significant (Bolton, 1997).

\section{Results}

Organoleptic analysis shows that the nature of root powder is coarse powder, slight brown in colour, acrid taste and has pungent and bitter in taste. The plant occurs in the Hills above $800 \mathrm{~m}$. It is a twiner. The leaves are cordate, coriaceous and densely pubescent below, lamina measuring upto $11 \times 7 \mathrm{~cm}$ in size. The petiole is $4 \mathrm{~cm}$ long. Flowers are unisexual, plant dioceious. Male flowers have 4 sepals, 4 petals and 4 stamens, female flowers have one sepals, one petals and monocarpellary, one ovuled ovary. Fruit is ovoid drupe. The roots are tuberous, cylindrical, irregularly curved, with grayish brown surface (Figure 1).

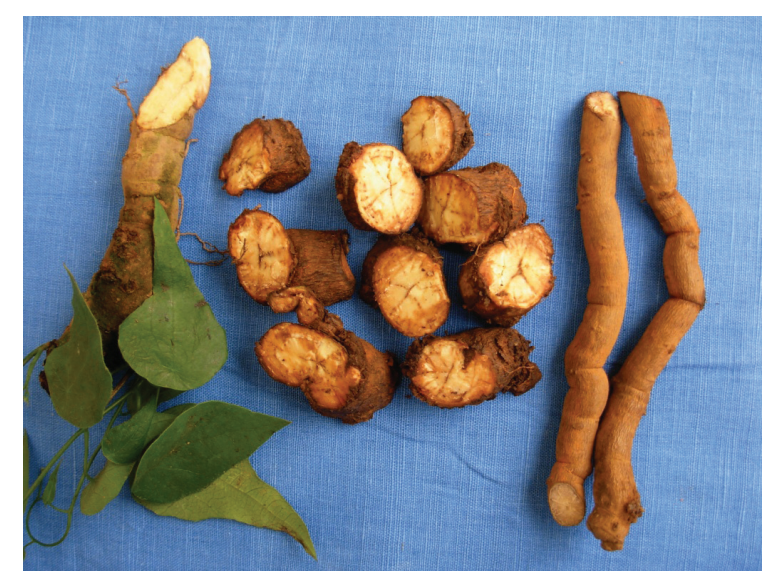

Figure1. Macroscopy of the tuberous roots and leafs of Cyclea peltata Hook. F. \& Thomson, Menispermaceae.

\section{Microscopic features of the leaf}

The leaf has prominent, plano-convex midrib which is semicircular on the abaxial part and flat on the adaxial part. The epidermal layer of the midrib consists of the circular, thick walled, fairly wide cells with prominent cuticle. Inner to the epidermis are two or three layers of small collenchymas cells. The palisade layer of the lamina extends upto the adaxial median zone, leaving a gap in the middle. The ground tissue of the midrib is parenchymatous; the cells are circular and fairly thick walled (Figure 2A). The midrib has a single, large collateral vascular strand placed in the central part of the midrib. It consists of a wide cluster of angular, thick walled xylem elements and a horizontal band of phloem elements. The vascular bundle is sheathed by a sclerenchyma layer of two or three cells thick (Figure 2A). The lateral vein does not project beyond the level of the lamina. It is similar to the midrib in structure. It consists of a small cluster of wide, thick walled angular xylem elements and a wide mass of phloem elements. The vascular bundle is surrounded by a thick layer of sclerenchyma bundle sheath. The cells are wide, thick walled and lignified (Figure 2B). The veinlets also have prominent vascular strand, occupying the entire mesophyll region of the lamina. It has a small nest of xylem and a cluster of phloem. The vascular strand is surrounded by wide sheath of parenchyma and adaxial and abaxial groups of sclerenchyma (Figure 2C). The lamina has even and smooths surfaces. The adaxial epidermis of the lamina consists of wide and thick rectangular cells. The abaxial epidermis is narrow and oblong. The mesophyll is differentiated into two layers of thick, cylindrical palisade cells and 6 or 7 layers of small lobed spongy parenchyma cells (Figure 2D). The leaf margin (Figure 2E) is slightly dilated and is blunt. It has an epidermal and subepidermal layer of small thick walled cells. These are a vascular strand situated at the submarginal part. The palisade zone is narrow and the spongy mesophyll is wide with several layers of lobed aerenchyma cells.

\section{Microscopic features of the root}

The root is $8 \mathrm{~mm}$ thick. The surface of the root is rough with shallow irregular fissures. The root exhibits unusual or anomalous type of secondary growth. When viewed under a low magnification, the root consists of an outer superficial periderm, cortical sclerotic cyclinder, a narrow central core of solid xylem from which radiate limited number of radial segments of xylem with wide inter-segmental parenchyma tissue. The vascular segments are narrow in the central part and become dilated toward the periphery. At the end of the xylem segments occurs a hemispherical cap of phloem (Figure 2F). The phloem consists of outer part of collapsed and crushed elements and inner intact part. The inner intact part has angular, thin walled phloem elements (Figure 2H). Xylem portion consists of wide, thin walled, circular, mostly solitary vessels, the ground tissue of the xylem segments is xylem fibres which are narrow, angular, thick walled and lignified (Figure $2 \mathrm{H}$ ). The rays that occur in behind the vascular segments consist of radial rows of rectangular parenchyma cells with dense accumulation of starch grains (Figure 2H and 2I).

The powdered microscopic preparation showed the following components when viewed under the microscope.

\section{Fragments of the lamina}

Broken fragments of the lamina are seen in abundance in the powder. The fragment exhibits the venation pattern. The venation is densely reticulate 
comprising thick lateral vein which gradually reduce in thickness cultivating into distinct and prominent vein termination. The vein islets are well defined which are variable in shape: they are squarish, triangular, rectangular or polyhedral in outline (Figure $3 \mathrm{~A}$ ). The vein terminations also vary. They are simple (un-branched), long and slender, sometimes, the terminations branch once or twice forming dendroid outline (Figure 3B). Another specific feature is that the vein termination is associated with wide, long, worm like sclereids. These terminal sclereids have thick secondary walls simple, canal-like pits and wide lumen (Figure 3C).

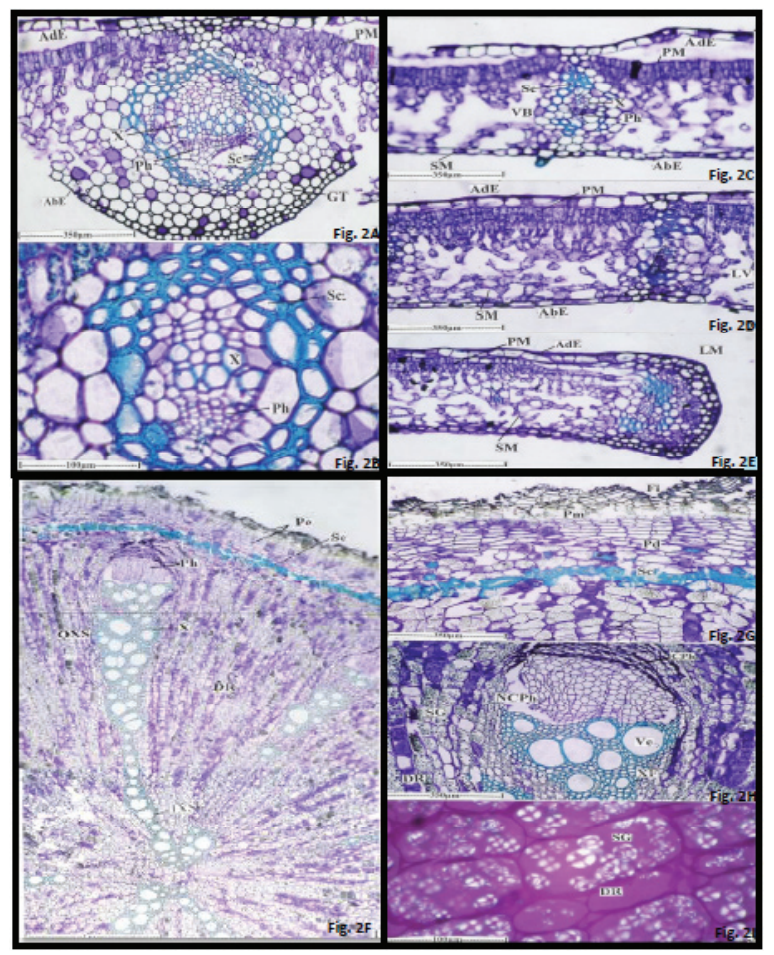

Figure 2. Microscopy of leafs and roots of of Cyclea peltata Hook. f. \& Thomson. 2A: Transversal section (TS) of leaf through midrib (10x). 2B: TS of vascular bundle of the lateral vein (40x). 2C: TS of lamina through lateral vein (10x). 2D: TS of lamina through veinlet (10x). 2E: TS of lamina through marginal part (10x). 2F: TS of tuberous-A section from centre towards periphery $(4 \mathrm{x}) .2 \mathrm{G}$ : TS of root through periderm $(10 \mathrm{x}) \cdot 2 \mathrm{H}$ : TS of root through outer segment of xylem and phloem cap (10x). 2I: starch grains in the xylem rays (as seen under polarized light microscope 40x). AbE: abaxial epidermis; AdE: adaxial epidermis; GT: ground tissue; LM: lateral margin; LV: lateral vein; $\mathrm{Ph}$ : phloem; $\mathrm{PM}$ : palisade mesophyll; Sc: sclerenchyma sheath; X: xylem; SM: spongy mesophyll; VB: vascular bundle; DR: dilated ray; IXS: inner xylem segment; OXS: outer xylem segment; Pe: periderm; $\mathrm{CPh}$ : collapsed phloem; Fi: fissures; NCPh: noncollapsed phloem; Pd: phelloderm; Ve: vessels; XF: xylem fibres.

\section{Tracheary elements}

Tracheary elements are cells in the xylem. They are tracheids, vessels and fibres. In the powder are seen tracheids, vessel elements of common type and fibriform vessel elements which are uncommon type.

a) Tracheids: are long, narrow cylindrical cells with dense bordered pits (Figure 3D and 3F).

b) Vessel elements: these elements are wide, short cylindrical cells. They have wide openings called perforations at the end walls. They have dense, multiseriate prominent, elliptic bordered pits on the lateral walls. The some of the vessel elements have short tails at the ends (Figure 3D, 3G, 3H and 3I).

c) Fileriform vessel elements: these elements are long, narrow cylindrical cells resembling the fibres; but they have end wall perforation plate and dense multiseriate bordered pits which are absent in the fibres. These elements are of unusual type (Figure 3E).

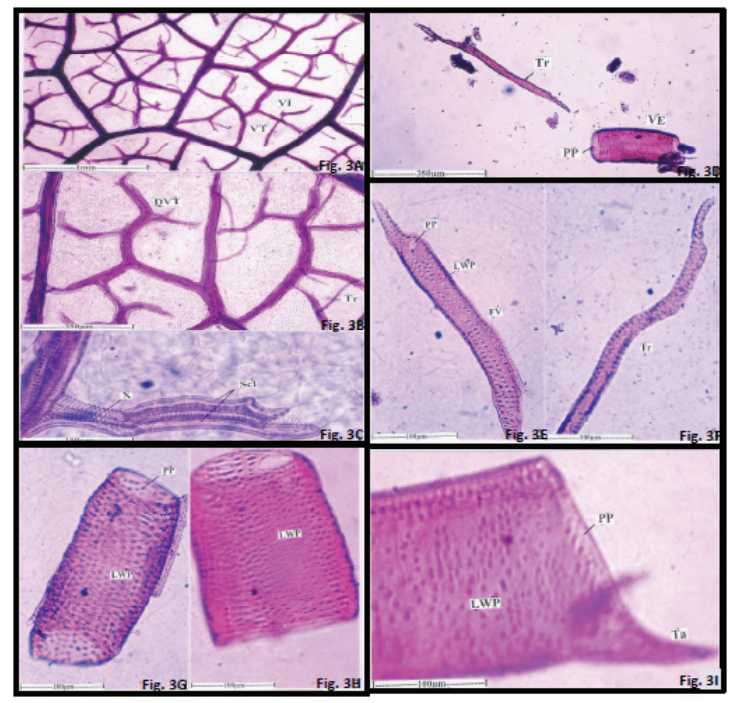

Figure 3. Powder microscopic observation of Cyclea peltata Hook. f. \& Thomson, Menispermaceae. 3A. Venation system of the lamina. 3B. Vein-islet and vein termination-enlarged. 3C. Sclereids associated with vein-termination. 3D. Tracheid and a vessel element in the powder. 3E. Fileriform vessel element. $3 F$. Terminal portion of the tracheid. 3G. Narrow cylindrical vessel element. 3H. Wider cylindrical vessel element. 3I. Vessel element with short tail. DVT: dendroid vein-termination; Sc: sclereids; Tr: tracheid; VI: vein-islet; VT: vein termination; X: xylem; FV: fileriform vessel element; LWP: lateral wall pits; PP: perforation plate; VE: vessel element.

\section{Physicochemical evaluation}

Ash values of a drug give an idea of the earthy matter or the inorganic composition and other impurities present along with the drug. The percentage of total ash, acid insoluble ash, sulphated ash and water soluble ash 
were carried out. The results are shown in Table 1.

Table 1. Ash values of Cyclea peltata Hook. f. \& Thomson, Menispermaceae, roots.

\begin{tabular}{lcc}
\hline Sl. No. & Ash values & $\begin{array}{c}\text { Results }(\% \mathrm{w} / \mathrm{w}) \\
\text { Vales are in mean } \pm \text { SE }\end{array}$ \\
\hline 1 & Total ash & $3.440 \pm 0.1$ \\
2 & Sulphated ash & $4.350 \pm 0.1$ \\
3 & Water insoluble & $2.900 \pm 0.2$ \\
& ash & $2.970 \pm 0.1$ \\
\hline
\end{tabular}

Extractive values are primarily useful for the determination of exhausted or adulterated drugs. The hexane soluble, petroleum ether soluble, dichloromethane soluble, chloroform soluble, acetone soluble, ethanol soluble and water soluble extractive values have been tabulated in Table 2. The results of fluorescence analysis of the root powder are tabulated in Table 3. Preliminary phytochemical screening revealed the presence of saponin, cardiac glycosides, alkaloids, hydrolyzable tannins, flavonoids, steroids and terpenoids.

Table 2. Percentage extractive values of Cyclea peltata Hook. f. \& Thomson roots.

\begin{tabular}{lcc}
\hline Sl. No. & Solvent & $\begin{array}{c}\text { Extractive value }(\% \mathrm{w} / \mathrm{w}) \\
\text { Vales are in Mean } \pm \mathrm{SE}\end{array}$ \\
\hline 1 & Hexane & $3.602 \pm 0.3$ \\
2 & Petroleum ether & $2.440 \pm 0.3$ \\
& $\left(60-80^{\circ} \mathrm{C}\right)$ & $5.640 \pm 0.2$ \\
3 & Dichloromethane & $2.430 \pm 0.2$ \\
4 & Chloroform & $3.630 \pm 0.1$ \\
5 & Acetone & $2.630 \pm 0.1$ \\
7 & Ethanol & $10.000 \pm 0.3$ \\
\hline
\end{tabular}

The antioxidant activity of petroleum ether, chloroform, ethyl acetate, ethanol and water plant extracts was evaluated according to their ability for scavenging free radicals by using ABTS assays and tabulated (Table 4). The percentage inhibition for ethanol, water and ethyl acetate extracts of $C$. peltata root was observered to be $90.71,70$ and 60.82 respectively.

Acid neutralizing capacity of $C$. peltata root powder showed no significant change in $\mathrm{pH}$ with respect to time. The root powder increased the $\mathrm{pH}$ from $1.1700 \pm 0.0100$ to $1.1900 \pm 0.0152$ and this constant in $\mathrm{pH}$ was observered for 30 and 60 min (Table 5).

Acute oral toxicity of HACP extract showed no mortality in rats at doses up to $2 \mathrm{~g} / \mathrm{kg}$. There were no toxicity signs observed on the skin, fur or eyes of the animals. No noticeable behavioral changes in salivation, sleeping pattern, diarrhea or lethargy were spotted in the treated animals. This result indicates that the hydroalcoholic extract of $C$. peltata is non-toxic, and safe upto $2 \mathrm{~g} / \mathrm{kg}$, b. wt. through oral route.

Table 3. Fluorescence analysis of Cyclea peltata Hook. f. \& Thomson roots.

\begin{tabular}{|c|c|c|c|}
\hline \multirow{2}{*}{ Sl. No. } & \multirow{2}{*}{ Treatment } & \multicolumn{2}{|c|}{ Observation under } \\
\hline & & Visible light & UV light \\
\hline 1 & Powder as such & Brown & Light green \\
\hline 2 & $\begin{array}{l}\text { Powdered drug + conc. } \\
\text { hydrochloric acid }\end{array}$ & Dark brown & Dark green \\
\hline 3 & $\begin{array}{c}\text { Powder }+80 \% \\
\text { sulphuric acid }\end{array}$ & Brown & $\begin{array}{l}\text { Blackish } \\
\text { green }\end{array}$ \\
\hline 4 & $\begin{array}{c}\text { Powder }+\underset{\text { acid }}{\text { glacial acetic }} \\
\end{array}$ & Light brown & Green \\
\hline 5 & $\begin{array}{l}\text { Powder + saturated } \\
\text { solution of picric acid }\end{array}$ & Yellow & Parrot green \\
\hline 6 & $\begin{array}{c}\text { Powder }+5 \mathrm{~N} \text { sodium } \\
\text { hydroxide }\end{array}$ & Pale brown & Light green \\
\hline 7 & $\begin{array}{l}\text { Powder }+5 \% \text { ferric } \\
\text { chloride solution }\end{array}$ & Yellowish brown & Dark green \\
\hline 8 & $\begin{array}{l}\text { Powder }+ \text { Aqueous } \\
\text { iodine solution }\end{array}$ & Black & Black \\
\hline
\end{tabular}

Table 4. ABTS free radical scavenging activity of different extracts of Cyclea peltata Hook. f. \& Thomson roots.

\begin{tabular}{lccc}
\hline \multirow{2}{*}{ Extract } & \multicolumn{3}{c}{$\begin{array}{c}\text { \% inhibition } \\
\text { (Average value) }\end{array}$} \\
\cline { 2 - 4 } & $50 \mu \mathrm{g}$ & $100 \mu \mathrm{g}$ & $150 \mu \mathrm{g}$ \\
\hline Pet. Ether & 10.95 & 18.33 & 21.46 \\
Chloroform & 4.05 & 19.05 & 45.48 \\
Ethyl acetate & 12.62 & 35.71 & 60.82 \\
Ethanol & 55.48 & 79.05 & 90.71 \\
Water & 45.00 & 56.67 & 70.00 \\
\hline
\end{tabular}

Table 5. Acid buffering activity of Cyclea peltata Hook. f. \& Thomson roots.

\begin{tabular}{lccc}
\hline \multirow{2}{*}{ Treatment } & \multicolumn{3}{c}{$\mathrm{pH}($ Mean $\pm \mathrm{SE})$} \\
\cline { 2 - 4 } & $1 \mathrm{~min}$ & $30 \mathrm{~min}$ & $60 \mathrm{~min}$ \\
\hline Control & $1.1700 \pm 0.0100$ & $1.1766 \pm 0.0088$ & $1.1733 \pm 0.0088$ \\
C. peltata & $1.1900 \pm 0.0152$ & $1.1900 \pm 0.0057$ & $1.1900 \pm 0.0057$ \\
\hline
\end{tabular}

The gastroprotection activity of HACP demonstrated significant anti-ulcerogenic activity in rats (Table 6). The HACP extract at the dose of $250 \mathrm{mg} / \mathrm{kg}$, b. wt showed to possess the highest protective effect with 94.41\% inhibition against ethanol-induced ulcerogenesis. Stomachs of all the animals treated with HACP at the dose of $500 \mathrm{mg} / \mathrm{kg}$, b. wt were completely protected from any visible damage (data not shown). 
Table 6. Effect of hydro-alcoholic extract of Cyclea peltata Hook. f. \& Thomson roots on Ulcer Index and Protective Index $(\%)$.

\begin{tabular}{lcccc}
\hline \multicolumn{1}{c}{ Treatment } & $\begin{array}{c}\text { Total } \\
\text { glandular area } \\
\text { (sq. mm) }\end{array}$ & $\begin{array}{c}\text { Total ulcerated } \\
\text { area } \\
\text { (sq. mm) }\end{array}$ & $\begin{array}{c}\text { Ulcer } \\
\text { index }\end{array}$ & $\begin{array}{c}\text { Protective } \\
\text { index (\%) }\end{array}$ \\
\hline $\begin{array}{l}\text { Diseased control } \\
\text { Sucralfate }\end{array}$ & $836.56 \pm 17.37$ & $122.05 \pm 17.60^{\#}$ & 1.4589 & - \\
$\begin{array}{l}(400 \mathrm{mg} / \mathrm{kg}, \text { p.o. }) \\
\text { HACP }\end{array}$ & $816.05 \pm 19.66$ & $59.22 \pm 8.61^{*}$ & 0.8482 & 51.47 \\
$(125 \mathrm{mg} / \mathrm{kg}$, p.o. $)$ & $849.45 \pm 27.12$ & $45.26 \pm 15.95^{*}$ & 0.5328 & 62.91 \\
$\begin{array}{l}\text { HACP } \\
(250 \mathrm{mg} / \mathrm{kg} \text {, p.o. })\end{array}$ & $979.02 \pm 23.45$ & $6.82 \pm 2.91^{* \#}$ & 0.0696 & 94.41 \\
\hline
\end{tabular}

Values are expressed as mean $\pm \mathrm{SE}(\mathrm{n}=6)$. ${ }^{*} p<0.01$ as compared with diseased control, $\# p<0.01$ as compared with standard control (sucralfate) (HACP: hydro-alcoholic extract of $C$. peltata roots).

\section{Discussion}

Organoleptic evaluation of crude drugs plays an important role in judging the censoring acceptability or rejection of crude drugs in the market. It is the technique of qualitative evaluation based on the study of morphological and sensory profile of whole drug (Kokate et al. 2002). The various morphological, microscopical, physicochemical standards developed in this study will help for botanical identification and standardization of the drug in crude form. The physical constant evaluation of the drugs is an important parameter in detecting adulteration or improper handling of drugs. The total ash is particularly important in the evaluation of purity of drugs i.e. presence or absence of foreign inorganic matter such as metallic salts and/or silica (Musa et al., 2006). The fluorescence analysis revealed that the powdered roots of Cyclea peltata Hook. f. \& Thomson, Menispermaceae,was treated various chemical reagents to give different colours (Table 3). Fluorescence is the phenomenon exhibited by various chemical constituents present in the plant material. Many phytocompounds fluoresce when suitably illuminated. The fluorescence colour is specific for each compound (Pimenta et al., 2006).

The antioxidant activity of ethanol and water extracts was observed to have good antioxidant activity, when compared with other extracts of $C$. peltata (Table 4). The percentage inhibition for ethanol and water extracts of C. peltata root was found to be 90.71 and 70 respectively. The roots of $C$. peltata were reported to contain the alkaloids D-tetrandrine and DL-tetrandrine (Rastogi \& Mehrotra, 1999) and this bisbenzylisoquinoline alkaloid is well known to possess antioxidant activity $(\mathrm{Ng}$ et al., 2006). Antacids are weak bases that react with gastric acid to form water and salt thereby diminishing gastric acidity. Acid neutralizing capacity depends upon capacity to neutralize gastric $\mathrm{HCl}$ and the extent of food contents in stomach (Hoeland \& Mycek, 2000). From the acid neutralizing capacity of the extract, it is well understood that the root extract is not having acid neutralizing capacity.

Acute oral toxicity studies divulged that the hydro-alcoholic extract of $C$. peltata is non-toxic, and safe at $2 \mathrm{~g} / \mathrm{kg}$, b. wt. through oral route. The flavonoids are also known as a naturally occurring compounds having gastroprotective effect (Villar et al., 1984 and Alarcon et al., 1994). Several mechanisms have been proposed to explain their biological effects; including increase of mucosal prostaglandin content, decrease of histamine secretion from mast cells, inhibition of acid secretion and inhibition of Helicobacter pylori growth. In addition, flavonoids have been found to be free radical scavengers; free radicals play an important role in ulcerative and erosive lesions of the gastrointestinal tract (Borrelli and Izzo, 2000).

Preliminary phytochemical analysis reveals that the extract shows the presence of saponins, which have been shown to possess anti-ulcer activity in several experimental ulcer models (Yesilada \& Gürbüz, 2003). The protective activities of these saponins may be due to the activation of mucous membrane protective factors, inhibition of gastric secretion volume and acid secretion (Saito et al., 1989).

On the other hand, $C$. peltata decreased the elevated levels of TNF- $\alpha$ in type 2 diabetic rats, this shows that $C$. peltata roots was also shown to possess an anti-inflammatory effect (Kirana \& Srinivasan, 2010). This might be of particular therapeutic importance as most of the anti-inflammatory drugs used in modern medicine are also ulcerogenic. However further studies are required to establish its exact mode of action and the active principles involved in this effect.

\section{Acknowledgements}

The authors are grateful to the vice-chancellor Prof. V. Sethuraman, SASTRA University for providing facilities to complete this research work and also to Dr. P. Jayaraman, Director, Plant Anatomy Research Center, Chennai for his help in pharmacognostical work of plant.

\section{Reference}

Alarcon C, Lastra L, Martin MJ, Casa C, Motilva V 1994. Antiulcerogenicity of the flavonoid fraction from Bidens aurea. Comparison with ranitidine and omeprazole. $J$ Ethnopharmacol 42: 161-168.

Ali M 2003. Text Book of Pharmacognosy, $2^{\text {nd }}$ ed. CBS Publishers and Distributers, New Delhi, p. 64-65.

Bolton S 1997. Analysis of variance. In: Swarbrick J. $4^{\text {th }}$ ed. Pharmaceutical statistics: practical and clinical applications. Drugs and Pharmaceutical Sciences Series. Basel: Marcel Dekker, p. 215-265. 
Borrelli F, Izzo AA 2000. The plant kingdom as a source of antiulcer remedies. Phytother Res 14: 581-591.

Chase CR, Pratt RJ 1949. Fluorescence of powdered vegetable drugs with particular reference to development of a system of identification. J Am Pharm Assoc 38: 324331.

Christina AJM, Packia Lakshmi M, Nagarajan M, Kurian S 2002. Modulatory effect of Cyclea peltata Lam. on stone formation induced by ethylene glycol treatment in rats. Methods Find Exp Clin Pharmacol 24: 77-79.

Esau K 1964. Plant anatomy, John Wiley and Sons, New York; p. 767.

Gutierrez-Cabano CA 2000. Protection by intragastric polyethylene glycol 400 in rat stomach against ethanol damage involves alpha2- adrenoceptors. Dig Dis Sci 45: 105-109.

Harborne JB 1998. Methods of plant analysis. In: Phytochemical Methods: A Guide to Modern Techniques of Plant Analysis. Chapman and Hall, London, p. 1-32.

Haseeb AK 2004. Computer-assisted visualization and quantitation of experimental gastric lesions in rats. $J$ Pharmacol Toxicol 49: 89-95.

Hoeland RD and Mycek MJ 2000. Lippincott's Illustrated Reviews: Pharmacology, Lippincott Williams and Wilkins, Philadelphia, p. 157-158; 240-241.

Indian Pharmacopoeia 1996. Ministry of Health and Family Welfare, New Delhi, India, p. A-47 and 54.

Johansen DA 1940. Plant Microtechnique, Mc Graw Hill Book Co: New York, p. 523.

Kirana H, Srinivasan BP 2010. Effect of Cyclea peltata Lam. roots aqueous extract on glucose levels, lipid profile, insulin, TNF- $\alpha$ and skeletal muscle glycogen in type 2 diabetic rats. Indian J Exp Biol 48: 499-502.

Kokate CK, Purohit AP, Gokhale SB 2002. Pharmacognosy, $20^{\text {th }}$ ed. Nirali Prakashan, Pune, p. 108-109.

Kokoshi J, Kokoski R, Slama FJ 1958. Fluorescence analysis of powered vegetable drugs under ultraviolet radiation. J Am Pharm Assoc 47: 75-77.

Musa KY, Katsayal AU, Ahmed A, Mohammed Z, Danmalam UH 2006. Pharmacognostic investigation of the leaves of Gisekia pharnacioides. Afr J Biotechnol 5: 956-957.

$\mathrm{Ng}$ LT, Chiang LC, Lin YT, Lin CC 2006. Antiproliferative and apoptotic effect of tetrandrine on different human hepatoma cell lines. Am J Chinese Med 34: 125-135.

O’Brien TP, Feder N, McCully ME 1964. Polychromatic staining of plant cell walls by Toluidine Blue-O. Protoplasma 59: 368-373.

Organization for Economic Cooperation and Development 2001. The OECD 423 Guideline for Testing of Chemicals Acute Oral Toxicity-Acute Toxic Class Method, Paris, France.

Pimenta AM, Montenegro MC, Araujo AN, Martínez JC 2006. Application of sequential injections analysis to pharmaceutical analysis. J Pharmaceut Biomed 40: 1634.
Rastogi RP, Mehrotra BN 1999. Cyclea (Menispermaceae). In: Rastogi RP, Editor, Compendium of Indian Medicinal Plants, vol. 2 (1970-1979), Central Drug Research Institute, Lucknow and National Institute of Science Communication, New Delhi, p. 237.

Re R, Pellegrini N, Proteggente A, Pannala A, Yang M, Rice-Evans C 1999. Antioxidant activity applying an improved ABTS radical cation decolorization assay. Free Radical Bio Med 26: 1231-1237.

Rifat-uz-Zaman, Akhtar MS, Khan MS 2002. Evaluation of acid buffering and pepsin bindingproperties of ispaghula (Plantago ovate, Forsk) and its extracts. Hamdard 45: 32-36.

Robert A, Nezamis JE, Lancaster C, Hanchar AJ 1979. Cytoprotection by prostaglandins in rats-Prevention of gastric necrosis produced by alcohol, $\mathrm{HCl}, \mathrm{NaOH}$, hypertonic $\mathrm{NaCl}$ and thermal injury. Gastroenterology 77: 433-443.

Saito H, Imanishi K, Okabe S 1989. Effects of Aloe extract, Aloctin A on gastric secretion and on experimental gastric lesions in rats. Yakugaku Zasshi 109: 335-339.

Sass JE 1940. Elements of Botanical Microtechnique. Mc Graw Hill Book Co; New York; p. 222.

Suleyman H, Akcay F, Altinkaynak K 2002. The effect of nimesulide on the indomethacin and ethanol induced gastric ulcer in rats. Pharmacol Res 45: 155-158.

The Ayurvedic Pharmacopoeia of India 1989. Department of Indian Systems of Medicine \&Homoeopathy, Government of India, Ministry of Health and Family Welfare, p. 1, 139 and 143.

Valiathan MS 2003. The Legacy of Charaka, Orient Longman Private Ltd., Chennai, p. 365-367.

Villar A, Gasco MA, Alcaraz MJ 1984. Anti-inflammatory and anti-ulcer properties of hypolaetin-8-glucoside, a novel plant flavonoid. J Pharm Pharmacol 36: 820-823.

WHO/QCMMPM 1992. Quality Control Methods for Medicinal Plant Material, Organization Mondiale De La Sante, Geneva, 22-34.

Yesilada E, Gürbüz I 2003. A compilation of the studies on the antiulcerogenic effects of medicinal plants. In: Singh, Surender, Singh, V.K., Govil, J.N. (Eds.), Recent Progress in Medicinal Plants, vol. II: Phytochemistry and Pharmacology. SCI Tech Publishing LLC, Houston, TX, p. 111-174.

\section{*Correspondence}

David Raj Chellappan

Division of Pharmacology and Toxicology, Centre for Advanced Research in Indian System of Medicine (CARISM)

SASTRA University, Thanjavur District, Tamil Nadu State, India

cdavidraj@carism.sastra.edu 